


\title{
Means for control over the activities of public authorities by civic democratic institutions: the conceptual framework analysis
}

\author{
DOI: https://doi.org/10.46398/cuestpol.3969.49
}

\author{
Iryna M. Gryshchenko * \\ Alina V. Denysova ** \\ Olga O. Ovsiannikova *** \\ Hanna S. Buha **** \\ Elena I. Kiselyova *****
}

\section{Abstract}

The purpose of the article is to develop the bases of citizen participation in the management of state affairs. The theme of the research is the participation of civil society in the process of integration in its different stages, as well as the conditions and processes of institutionalization of civil society. The objective is to study the forms of participation of civil society in the integration process and the dynamics of institutionalization of the latter. Comparative analysis was a key method. The results show that democratic civic institutions in countries with a high level of socio-economic development show a higher level of political activity than democratic institutions with a low level of socioeconomic development. The effectiveness of control over the activities of public authorities is greater in the institutional agents of civil society than in the individual ones. In conclusion, the list of forms of interaction between civic and public institutions was expanded. Moreover, the article identifies new elements of the legislative machine for the control of public authorities by democratic civic institutions that seek to increase social control in thepoliticalsystem.

* Doctor of Administrative Sciences, Associate. Professor of the Department of Public Administration and Innovation Management, National University of Life and Environmental Sciences of Ukraine. ORCID ID: https://orcid.org/oooo-0oo2-8191-1177. Email: Gryschenkoiryna45@ukr.net

** Doctor of Law, Associate Professor, Head of Department of Administrative Law and Administrative Process, Odesa State University of Internal Affairs. ORCID ID: https://orcid.org/oooo-0001-55519297. Email: apapoduvst@gmail.com

** PhD in Law, Associate Professor of the Department of Judicial Organization and Prosecutorial Activities, Yaroslav Mudryi National Law University. ORCID ID: https://orcid.org/oooo-0001-77736487. Email: olgaalexovs45@gmail.com

**** PhD in Law, Associate Professor of the Department of Administrative and Law Disciplines, Faculty 2, Donetsk Law Institute of MIA of Ukraine. ORCID ID: https://orcid.org/oooo-0003-3957-7387. Email: annabuha84@gmail.com

***** Doctor of Law, Professor at the Department of Administrative, Economic Law and Financial and Economic Security, Educational-Scientific Institute of Law, Sumy State University. ORCID ID: https:// orcid.org/oooo-0002-5625-0952. Email: lenakiseleva2005@gmail.com 
Keywords: judicial power; public opinion; public organizations; public administration; public authority.

\title{
Medios de control sobre las actividades de las autoridades públicas por parte de las instituciones cívicas democráticas: el análisis del marco conceptual
}

\begin{abstract}
Resumen
El propósito del artículo es desarrollar las bases de la participación ciudadana en la gestión de los asuntos estatales. El tema de la investigación es la participación de la sociedad civil en el proceso de integración en sus diferentes etapas, así como las condiciones y procesos de institucionalización de la sociedad civil. El objetivo es estudiar las formas de participación de la sociedad civil en el proceso de integración y las dinámicas de institucionalización de la esta. El análisis comparativo fue un método clave. Los resultados evidencian que las instituciones cívicas democráticas en países con un alto nivel de desarrollo socioeconómico muestran un mayor nivel de actividad política que las instituciones democráticas con un bajo nivel de desarrollo socioeconómico. La efectividad del control sobre las actividades de los poderes públicos es mayor en los agentes institucionales de la sociedad civil que en los individuales. A modo de conclusión se amplió la lista de formas de interacción entre instituciones cívicas y públicas. Por lo demás, el artículo identifica nuevos elementos de la máquina legislativa para el control de las autoridades públicas por parte de las instituciones cívicas democráticas que buscan incrementar la contraloria social en el sistema político.
\end{abstract}

Palabras clave: poder judicial; opinión pública; organismos públicos; administración pública; autoridad pública.

\section{Introduction}

An analysis of different scientific positions allows us to conclude that civic society is considered an intermediary sphere in which market participants act, and which significantly stands out from public authorities. Scientists interpret the term "civic institution" comprehensively, considering as such not only public organizations, but also funds, municipalities and communal associations of citizens, research and educational institutions, trade unions, employers associations and industry associations, non-profit media and other parties concerned (Ardag et al., 2019). 
Strengthening the role of EU civic institutions in Eastern Europe is often accompanied by the provision of equal financial and technical support to local civic institutions. The EU also uses a cooperation model based on partnerships between public authorities and civic institutions (McGregor, 2019).

This is mostly due to the willingness of local civic institutions to cooperate with external actors such as the EU, as well as with other civic society actors in Eastern Europe. In addition, civic institutions in Eastern European structurally weak democratic states require information, material and technical support. Therefore, as a rule, they need to have the necessary organizational structure or professional potential.

For the EU, civic institutions are advantageous as cooperation partners due to their social orientation. This makes it much easier for EU institutions to find a suitable social protection partner.

If we consider the positions of scientists who study the influence of civic institutions on the public policymaking in various spheres of public life (Abou-Chadi and Krause, 2020), they come down to the following scheme (Figure 1):

Figure 1: Evolution of civic institutions' influence on the activities of public authorities

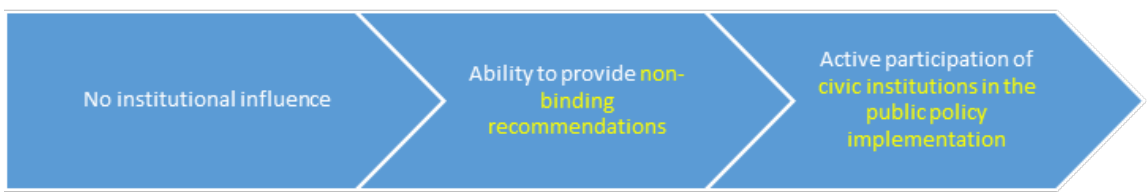

Source: own elaboration

Supporters of the position that there is no civic institutions' influence on the state policy implementation, as well as control over its implementation, exclude the need for a "public and state sovereignty war", which destructively affects the state and society development (Denedo et al., 2019). There are researchers who emphasize the negative potential of civic institutions - the spread of separatist, chauvinistic, racist appeals, which prevents them from becoming a state power tool actor (Howell, 2019). 
Supporters of the position regarding the participation of civic institutions in the activities of government entities having an advisory vote right believe that the scope of powers of public authorities significantly prevails the scope of powers of civic institutions. This is necessary to ensure the law and order in the state and society. Therefore, civic institutions should not strive to become "unofficial government" (Han et al., 2020).

The active participation of civic institutions in the state policy implementation is a minority position in the scientific field. After all, the means of contol and balance does not provide for the participation of civic institutions in the executive authority's system. The research complexity also depends on difficulty to track and evaluate the activities of civic institutions using technical or sociological methods. In addition, the legislation of the studied countries defines the scope of rights and obligations, the procedure for establishment and activities of civic institutions in different ways. However, it was possible to develop a number of scientific indicators to analyse the activities of civic institutions (Chatain and Plaksenkova, 2017; Liinason, 2020).

Here are two examples of proposed systems for civil society evaluation - first was developed thanks to the efforts of like-minded activists, second - thanks to scientists:

- The Civil Society Index (CSI) was developed by the Civicus international organization, which positions itself as the global alliance of civil society organisations and activists. The center of this organization is headquartered in Johannesburg, South Africa.

- The Global Civil Society Index (GCSI) was developed by the John Hopkins' Center for Civil Society Studies, USA.

However, assessing the general level of civic institutions development, we can talk about their active development in Western Europe and North America countries. At the same time, most researchers note the weakness of civic institutions in Central and Eastern Europe. Therefore, the need to develop effective powers to control of civic institutions predetermines the relevance of this research.

\section{Underlying Hypothesis}

Our research is based on three hypotheses:

1. The first hypothesis is that the civic democratic institutions' participation in the process of control over the activities of public authorities is irregular: civic democratic institutions in countries with a high level of socio-economic development show a higher level of social activity than democratic institutions with low level of socio-economic development. This is because the process of the 
Iryna M. Gryshchenko, Alina V. Denysova, Olga O. Ovsiannikova, Hanna S. Buha y Elena I. Kiselyova

legal framework development for the civic institutions' activities and the institutionalization of the interaction for civil society with the European Union institutions proceeded consistently from the establishment of the integration association.

2. The second hypothesis is that the effectiveness of control over the activities of public authorities is higher in institutional actors of civil society than in individual ones.

\section{Literature Review}

Civic institutions are the research basis for many scholars, but Bolleyer (2018) deserves special attention, as the first attempt too examine these issues across a wide range of western democratic traditions. The reasearcher writes a second book that studies the various ways of civic institutions to develop civil society participation and advocacy. In short, Bolleyer experience and research can help civil society to accept it changing role and provide information on upcoming legal decisions. The author explained:

There is a democratic crisis across Europe and many people are turning their backs on politics, making civic institutions more important than ever for linking citizens and government entities. Therefore, there is a question as to how the state itself, through certain legislative decisions, intentionally or unintentionally governs these opportunities (Bolleyer, 2018: 125).

From European point of view, for some time, there have been trends towards strengthening government regulation of civil society. These events have accelerated in recent years. Actions to overcome the terrorism have contributed to the development of a so-called "diminishing field of maneuver for civil society", leaving civil society less and less opportunities for effective self-expression and influence on decision-making - a phenomenon recognized by the EU, the Council of Europe and various non-governmental organizations. COVID-19 has also contributed to this alarming trend (Goncharenko, 2019).

In the work by Greenberg and Rubinstein (2013) the civic institutions are considered as an effective tool for protecting citizens from the public authorities' arbitrariness. A real opportunity for citizens to use democratic governance powers. If we consider the civic institutions influence from the standpoint of research, then it is worth highlighting several basic directions (Jia, 2019).

Representatives of the first direction carried out comparisons of various democratic regimes. The focus of the study was the statement that the increased dependence of civil society on government funding and regulation will have negative consequences for the society internal functioning and 
activities. The legislation was studied and its impact on parties, interest groups and civic institutions was assessed (Bolleyer, 2018).

The research results can be divided into two categories: many scholars believe that there is a general tendency towards the adoption of more or less restrictive regulations, depending on the traditions of law and state, as well as the corresponding democratic history. This means that different democracies, more or less resistant to the civil society space erosion, when faced with exceptional circumstances (such as terrorism or the current pandemic), foster more restrictive legislation (Jones and Malis, 2020).

Other scholars have noticed different consequences of different relationships between state and society. For example, members of organizations that rely heavily on paid staff, which often becomes possible and is enhanced by government funding, tend to have less influence over internal decisions. In other words, they are less democratic within the country (Denedo et al., 2019).

McGregor (2019) studies the civil society contribution to democracy in more detail. "Essentially, the study shows the complex consequences of central organizational properties, such as qualification level or dependence on government funding. In particular, the study examines the participation of community members in the organization and whether the political interest group can respond to social demands and concerns".

The second direction is aimed at the typology and classification of democratic institutions, as well as their control measures (Han et al., 2020).

Representatives of the third direction consider the prospects for a radical change in the civil society development vector, its transition to the political level, which provides real management capabilities. We find this position in the work of White (1975).

Studying the forms of civil society in Europe, foreign researchers note, first of all, differences between the structure and level of participation Western Europe, Central and Eastern Europe citizens in the civic institution's activities (Wang et al., 2020). This is the fourth direction related to research on social and volunteer activities of civic institutions.

The fifth direction is the relationship between the public authorities and civic institutions, through the provision of social and public services. In this case, we are talking about the real empowerment of some civic institutions to implement social protection and provide public services (Rochlitz et al., 2020).

However, despite the difference in legislation, the difficulties of legal implementation, the opposite views of scientists, we come to a general conclusion: the civic institutions are important. At the primary level, they contribute to the self-organization of people. They transform the population 
Iryna M. Gryshchenko, Alina V. Denysova, Olga O. Ovsiannikova, Hanna S. Buha y Elena I. Kiselyova

802

Means for control over the activities of public authorities by civic democratic institutions: the conceptual framework analysis

of the country into the nation - the real possessors of public, control and regulatory powers. The development of effective means for civic institutions' participation in management and control is the way to preserve peace and the state territorial integrity (Snellen, 2002).

\section{Methods and Materials}

The research includes neofunctionalism studies, which have a significant impact on the civil society development. The research also studies the liberal intergovernmental approach, which substantiates the European integration process solely by the actions and interests of the member states, which directly concerns the civic institutions activities. According to the liberal intergovernmental approach, while maintaining state "diversity", control over the society life processes should remain in hands of states, within which civil societies exist and develop. Thus, decisions concerning the civic institutions activities are the result of mutual compromises of the member states.

The author also used the method of comparative analysis for data obtained by research centers through a sociological survey, involved observation, questionnaires, interviews, and an expert survey.

The comparative study was carried out between August 2020 and January 2021. The study was carried out in three stages (Figure 2).

Figure 2: Study stages

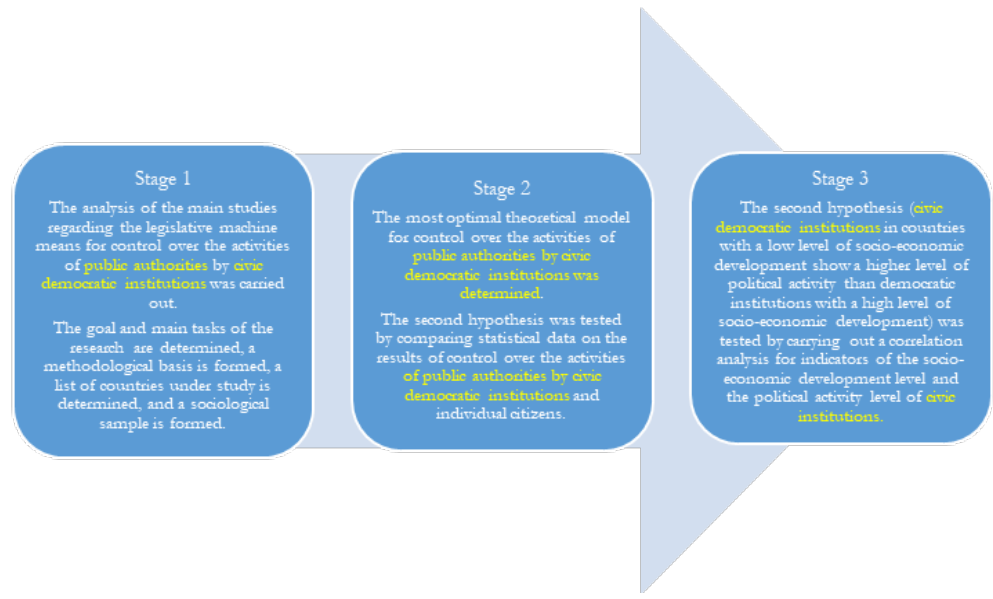

Source: Author's development. 
At the first stage of the study, using special scientific methods (comparative analysis, analysis of experts' positions, online sociological survey), the collection and processing of information on the means of control over the activities of public authorities by civic democratic institutions was carried out.

The method of conceptual analysis requires detailed study in the context of the indicated political research, since it is used to disclose the existing means for control over the activities of public authorities by civic democratic institutions.

\subsection{Research Design}

A sociological experimental procedure is the empirical basis of analytical research at the third stage of the study. The sociological experimental procedure includes 5 stages: preparation; organization; implementation; analytical data analysis; research results presentation. We used data from a survey conducted in 15 countries from May to October 2020, with 30.000 respondents. The data are included in the Democratic Rights Popular Globally but Commitment to Them Not Always Strong analytical report.

The correlation analysis carried out by the author is the empirical basis of the research at the third stage of the study. The aim of correlation analysis is to calculate the correlation coefficients. Correlation coefficients can take, as a rule, positive and negative values. The correlation coefficient sign makes it possible to interpret the connection direction, and the absolute value - the connection strength.

\section{Results}

From the author's point of view, the means for civil control include exercising actors, civil control object; ways of civil control exercising; social relations that arise while civil control exercising (Figure 3). 
Iryna M. Gryshchenko, Alina V. Denysova, Olga O. Ovsiannikova, Hanna S. Buha y Elena I. Kiselyova

Figure 3: Means of civil control

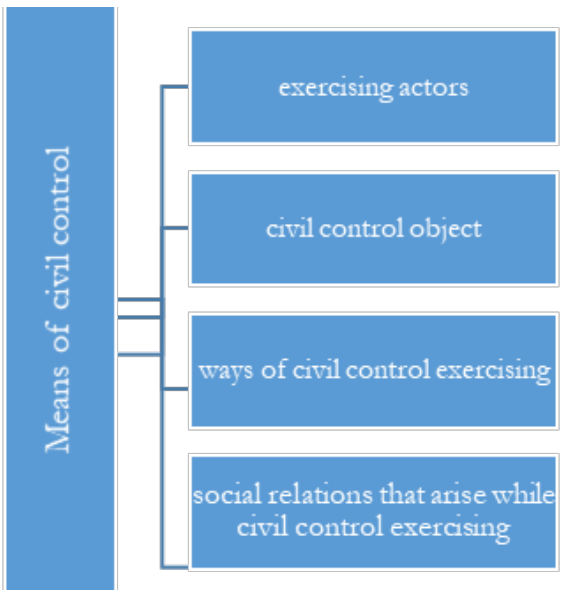

Source: own elaboration

Let us consider the means for civil control in more detail:

Exercising actors: undoubtedly, these are public authorities and civic institutions. We consider various kinds of civic institutions, both in terms of their activity range (international, national and local) and in terms of their activity field (economic, social, volunteer, youth). In order to enforce their legal personality in "state-society" relations, civic institutions should have a sufficient number of rights in the social control field. For example, the right to individual requests, to participate in community councils or public hearings. It is also necessary to establish the responsibility of public authorities for ignoring and creating obstacles in the activities of civic institutions at the legislative level.

Civil control object is the activity of state and municipal bodies regarding the budget distribution and use, the implementation of social and economic development programs, social facilities construction, human and civil rights protection.

Ways of civil control exercising are the activities of civic institutions, which include the possibility of conducting control measures, checks, inspections, studying reporting, conducting sociological and scientific research.

Social relations that arise while civil control exercising. As a rule, relations arising from interaction with public authorities and local selfgovernment authorities are imperative, but if we are talking about the 
control exercising, it is obvious that relations should be based on the principles of equality. According to the sector-specific criterion, legal relations between the state and civil society can be divided into: legal relations in the economic development field, legal relations between civic institutions cooperating with universities in order to increase the efficiency and transparency of the public sector in key spheres of society; legal relations between public authorities and youth organizations to promote sports; legal relations of civic institutions (associations of employers, manufecturers, trade unions, creative unions) that interact with the state in the social and labor relations field - protection of labor and social rights of citizens, coordination of enterprises' activities, upholding the interests of professional groups; legal relations between the state and civic institutions regarding the development of youth patriotic education system; legal relations with lawyers associations in order to develop citizens' awareness of their rights and freedoms; legal relations with public organizations in social and volunteer spheres regarding the provision of social services to indigent categories of citizens; legal relations between civic institutions (non-state media, journalists associations) that interact with the state in the social information space field - distribution of information, receipt of information, protection and analysis of information and rights; relations between the state and educational public organizations to ensure high quality of educational services, as well as the human right to education; legal relations between civic institutions (youth and children's public organizations, women's movements) that interact with citizens, including the unconstrained exercising of youth and gender policies by citizens; legal relations of civic institutions (all types of religious organizations) that interact with the state on the constitutional rights of citizens and freedom of religion - protect the unconstrained use of all prohibited forms.

Sociological research analysis is necessary in order to make a comparative analysis of the effectiveness of control over the activities of public authorities among institutional actors and individual ones. The research was carried out in two directions:

1. A comparative analysis of the analytical report data by Wike and Schumacher (2020) was carried out (Table 1).

2. Author's online sociological surveys (5000 respondents $(\mathrm{N}=5000)$ ) were conducted, the sample scope is $7 \%$ (Table 2).

The analysis of the data represented in Table 1 confirms the Hypothesis No. 2 that the effectiveness of control over the activities of public authorities is higher among institutional actors than among individual ones. 
Iryna M. Gryshchenko, Alina V. Denysova, Olga O. Ovsiannikova, Hanna S. Buha y Elena I. Kiselyova

806

Means for control over the activities of public authorities by civic democratic institutions: the conceptual framework analysis

Table 1. Democratic rights popular globally but commitment to them not always is strong

\begin{tabular}{|c|c|c|}
\hline Countries & $\begin{array}{c}\text { Percentage of } \\
\text { civic institutions } \\
\text { participating in control } \\
\text { measures \% }\end{array}$ & $\begin{array}{c}\text { Percentage of socially } \\
\text { active citizens who are not } \\
\text { members of civic democratic } \\
\text { institutions \% }\end{array}$ \\
\hline France & 72 & 28 \\
\hline UK & 72 & 31 \\
\hline Sweden & 68 & 31 \\
\hline Germany & 66 & 36 \\
\hline Hungary & 66 & 36 \\
\hline Netherlands & 63 & 39 \\
\hline Bulgaria & 60 & 45 \\
\hline Poland & 57 & 50 \\
\hline Greece & 57 & 32 \\
\hline Lithuania & 55 & 31 \\
\hline Slovakia & 55 & 27 \\
\hline Czech Rep & 49 & 26 \\
\hline Italy & 46 & 34 \\
\hline Ukraine & 35 & 30 \\
\hline Russia & 41 & 30 \\
\hline
\end{tabular}

Source: Wike and Schumacher (2020).

Table 2. Results of sociological research conducted by the author

\begin{tabular}{|c|c|c|c|c|c|c|c|c|c|}
\hline \multirow{2}{*}{$\begin{array}{c}\text { Questions and } \\
\text { answers }\end{array}$} & \multicolumn{9}{|c|}{ Countries } \\
\cline { 2 - 10 } & France & UK & Sweden & Germany & Hungary & Greece & Italy & Ukraine & Russia \\
\hline $\begin{array}{c}\text { Do you take } \\
\text { part in public } \\
\text { events held in } \\
\text { your region? }\end{array}$ & & & & & & & & & \\
\hline Yes & $37 \%$ & $45 \%$ & $49 \%$ & $22 \%$ & $26 \%$ & $34 \%$ & $56 \%$ & $87 \%$ & $55 \%$ \\
\hline No & $63 \%$ & $55 \%$ & $51 \%$ & $78 \%$ & $74 \%$ & $66 \%$ & $44 \%$ & $13 \%$ & $45 \%$ \\
\hline $\begin{array}{c}\text { Are you a } \\
\text { member } \\
\text { of a public } \\
\text { organization? }\end{array}$ & & & & & & & & & \\
\hline
\end{tabular}


CUESTIONES POLÍTICAS

Vol. 39 No 69 (Julio - Diciembre 2021): 796-813

\begin{tabular}{|c|c|c|c|c|c|c|c|c|c|}
\hline Yes & $45 \%$ & $34 \%$ & $45 \%$ & $47 \%$ & $37 \%$ & $56 \%$ & $58 \%$ & $69 \%$ & $45 \%$ \\
\hline No & $55 \%$ & $66 \%$ & $55 \%$ & $53 \%$ & $63 \%$ & $44 \%$ & $42 \%$ & $31 \%$ & $55 \%$ \\
\hline \multicolumn{10}{|c|}{$\begin{array}{c}\text { In your } \\
\text { opinion, do } \\
\text { the citizens } \\
\text { of your state } \\
\text { influence } \\
\text { the activities } \\
\text { of state } \\
\text { authorities? }\end{array}$} \\
\hline Yes & $80 \%$ & $82 \%$ & $78 \%$ & $57 \%$ & $67 \%$ & $56 \%$ & $45 \%$ & $22 \%$ & $30 \%$ \\
\hline No & $20 \%$ & $18 \%$ & $22 \%$ & $43 \%$ & $33 \%$ & $44 \%$ & $55 \%$ & $78 \%$ & \\
\hline \multicolumn{10}{|c|}{$\begin{array}{c}\text { In your } \\
\text { opinion, do } \\
\text { the public } \\
\text { organizations } \\
\text { of your state } \\
\text { influence } \\
\text { the activities } \\
\text { of state } \\
\text { authorities? }\end{array}$} \\
\hline Yes & $82 \%$ & $90 \%$ & $87 \%$ & $83 \%$ & $79 \%$ & $59 \%$ & $65 \%$ & $36 \%$ & $33 \%$ \\
\hline No & $18 \%$ & $10 \%$ & $13 \%$ & $17 \%$ & $21 \%$ & $41 \%$ & $35 \%$ & $64 \%$ & $67 \%$ \\
\hline \multicolumn{10}{|c|}{$\begin{array}{c}\text { Have you } \\
\text { ever appealed } \\
\text { against } \\
\text { actions or } \\
\text { inactions } \\
\text { of state } \\
\text { authorities? }\end{array}$} \\
\hline Yes & $34 \%$ & $25 \%$ & $34 \%$ & $24 \%$ & $36 \%$ & $35 \%$ & $45 \%$ & $65 \%$ & $40 \%$ \\
\hline No & $66 \%$ & $75 \%$ & $66 \%$ & $76 \%$ & $64 \%$ & $65 \%$ & $55 \%$ & $35 \%$ & $60 \%$ \\
\hline \multicolumn{10}{|c|}{$\begin{array}{c}\text { In your } \\
\text { opinion, } \\
\text { are public } \\
\text { institutions } \\
\text { a real } \\
\text { alternative } \\
\text { to state } \\
\text { institutions in } \\
\text { your country? }\end{array}$} \\
\hline Yes & $65 \%$ & $76 \%$ & $56 \%$ & $76 \%$ & $75 \%$ & $83 \%$ & $78 \%$ & $25 \%$ & $30 \%$ \\
\hline No & $35 \%$ & $24 \%$ & $44 \%$ & $24 \%$ & $25 \%$ & $17 \%$ & $22 \%$ & $75 \%$ & $70 \%$ \\
\hline
\end{tabular}

Source: own elaboration

To confirm the Hypothesis No.1 that civic democratic institutions in countries with a high level of socio-economic development show a higher level of social activity than democratic institutions with a low level of socio-economic development, we used the method of correlative analysis. 
Iryna M. Gryshchenko, Alina V. Denysova, Olga O. Ovsiannikova, Hanna S. Buha y Elena I. Kiselyova

808

Means for control over the activities of public authorities by civic democratic institutions: the conceptual framework analysis

We have determined the correlation between the Sustainability Index for Central and Eastern Europe and Eurasia and GDP (PPP) per capita data as of 2019 (Table 3).

Table 3. The 2019 CSO Sustainability Index for Central and Eastern Europe and Eurasia GDP (PPP) per capita 2019

\begin{tabular}{|c|c|c|}
\hline Country & $\begin{array}{c}\text { Sustainability Index for } \\
\text { Central and Eastern Europe } \\
\text { and Eurasia }\end{array}$ & $\begin{array}{c}\text { Eastern Europe and } \\
\text { Eurasia Ta GDP(PPP) } \\
\text { per capita }\end{array}$ \\
\hline France & 45.454 & 42878 \\
\hline UK & 44.288 & 42558 \\
\hline Sweden & 68.340 & 82950 \\
\hline Germany & 53.571 & 48264 \\
\hline Hungary & 32.434 & 15924 \\
\hline Netherlands & 57.101 & 53106 \\
\hline Bulgaria & 23.741 & 9267 \\
\hline Poland & 33.739 & 15431 \\
\hline Greece & 29.045 & 20408 \\
\hline Lithuania & 38.605 & 18032 \\
\hline Slovakia & 32.184 & 19582 \\
\hline Czech Rep & 40.293 & 22850 \\
\hline Italy & 40.066 & 34260 \\
\hline Ukraine & 12.710 & 2963 \\
\hline
\end{tabular}

Source: Civil Society Organization (2020); Wikipedia (n.d.).

According to Figure 4, the Pearson correlation coefficient is 0.96971526 for the sanple size 20, regarding that zL lower 95\% limit is 1.61213911 and zU upper 95\% limit is 2.56286129, which confirms the Hypothesis No.1. 
Figure 4: Pearson correlation coefficient

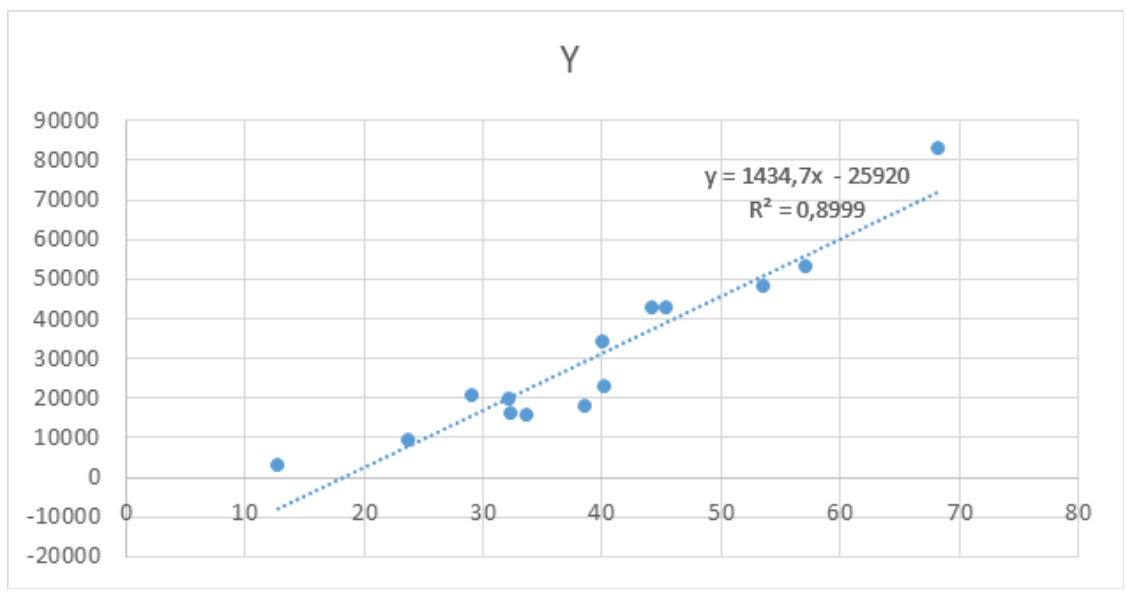

Source: own elaboration

\section{Discussion}

The interaction of civic institutions and public authorities became the object for scientific research for many scientists, in particular Mizrahi et al., (2021) defined a meaningful concept of intersectoral social partnership, which is based on non-political nature of public authorities and civic institutions interaction. There are discussions about the apolitical, only social nature of civic institutions activities (Leach, 2018). Scientists increasingly deny the participation of citizens and civic institutions in legal relations of a peremptory nature (Germino, 1990). They are considered a social-volunteer auxiliary institutions, which are deprived of managerial and control powers in general (Ernazarov, 2020). Representatives of many civic institutions consider participation in political struggle, the exercise of control and supervisory powers destructive for their activities (Adloff and Neckel, 2019).

In the "Cross-Country Comparisons of Civil Institutions Societies: an Empirical Analysis" article, the Russian scientist Liebman (2010) identifies three main approaches to assessing civil society presented in modern literature. The first scientific approach involves a mathematical assessment of civic institutions activities using a system of integral indices. Among them are: Civil Society Index - CSI; Civil Society Strength Index - CSSI; Global Civil Society Index - GCSI (Bryhinets et al., 2020). 
The opposite is the second approach, its representatives propose to completely move away from the index assessment of the civic institutions activities and return to the assessment of the qualitative component of their activities (Howlett, 2020).

The third approach involves the study of more specific issues regarding the civic institutions activities. This analysis can be carried out using indicators that, although they do not define the civic institutions activities, but characterize the civil society development at various stages and in various areas: the index of non-governmental organizations sustainability - NGOS. DD - direct democracy index - refers to freedom index, anticorruption perception index, world press freedom index. Of course, all of them, to one degree or another, partially describe the level of civic institutions development, however, they are not comprehensive (Liebman, 2010).

\section{Conclusion}

Summing up, the results of our sociological, empirical and comparative studies, as well as world experience show that the powers to control of civic institutions today are only a model of public relations, which we strive to implement. As a result of this research, the author proposed to develop effective means for civil control exercising, which includes exercising actors, civil control object; ways of civil control exercising; social relations that arise while civil control exercising.

The authors of this research concluded that civic democratic institutions in countries with a high level of socio-economic development show a higher level of social activity than democratic institutions with a low level of socioeconomic development. The effectiveness of control over the activities of public authorities is higher among institutional actors than among individual ones.

\section{Bibliographic References}

ABOU-CHADI, Tarik; KRAUSE, Werner. 2020. "The causal effect of radical right success on mainstream parties' policy positions: A regression discontinuity approach.” In: British Journal of Political Science, Vol. 50, No. 3, pp. 829-847.

ADLOFF, Frank; NECKEL, Sighard. 2019. "Futures of sustainability as modernization, transformation, and control: a conceptual framework" In: Sustainability Science. Vol. 14, pp. 1015-1025. 
ARDAG, Murat M; CASTANHO SILVA, Bruno; THOMECZEK, J. Philipp; BANDLOW-RAFFALSKI, Steffen F; LITTVAY, Levente. 2019. "Populist attitudes and political engagement: Ugly, bad, and sometimes good?" In: Representation. (Ahead of print). Available online. In: https://doi.org/1 0.1080/00344893.2019.1661870. Date of consultation: 20/02/2021.

BOLLEYER, Nicole. 2018. "The State and Civil Society: Regulating Interest Groups, Parties, and Public Benefit Organizations in Contemporary Democracies" Oxford University Press. Oxford, UK.

BRYHINETS, Oleksandr. O; SVOBODA, Ivo; SHEVCHUK, Oksana. R; KOTUKH, Yevgen. V; RADICH, Valentyna. Y. 2020. "Public value management and new public governance as modern approaches to the development of public administration” In: Revista San Gregorio. Vol. 42, pp. 205-215.

CHATAIN, Olivier; PLAKSENKOVA, Elena. 2017. "NGOs and the Creation of Value in Supply Chains.” Available online. In: https://doi.org/10.2139/ ssrn.2925276. Date of consultation: 20/12/2020.

CIVILSOCIETYORGANIZATION.2020,October. “The 2019CSOSustainability Index for Central and Eastern Europe and Eurasia." In: U.S. Agency for International Development. Washington DC, USA.

DENEDO, Mercy; THOMSON, Ian; YONEKURA. Akira. 2019. "Ecological damage, human rights and oil: local advocacy NGOs dialogic action and alternative accounting practices" In: Accounting Forum. Vol. 43, No. 1, pp. 85-112.

ERNAZAROV, Dilmurod Zukhriddinovich. 2020. "Analysis of the policy of the Republic of Uzbekistan regarding international non-governmental organization" In: Journal of Political Science and International Relations. Vol. 3, No. 1, pp. 9-15.

GERMINO, Dante L. 1990. "Antonio Gramsci: Architect of a New Politics." Louisiana State University Press. Baton Rouge, USA.

GONCHARENKO, Galina. 2019. "The accountability of advocacy NGOs: Insights from the online community of practice.” In: Accounting Forum, Vol. 43, No. 1, pp. 135-160.

GREENBERG, Ruslan Semyonovich; RUBINSTEIN, Alexandr Yakovlevich. 2013. "Individual and State: Economic Dilemma." Ves' Mir. Moscow, Russia.

HAN, Xuehua; WANG, Juanle; ZHANG, Min; WANG, Xiaojie. 2020. "Using social media to mine and analyze public opinion related to COVID-19 in 
Iryna M. Gryshchenko, Alina V. Denysova, Olga O. Ovsiannikova, Hanna S. Buha y Elena I. Kiselyova

812

Means for control over the activities of public authorities by civic democratic institutions: the conceptual framework analysis

China" In: International Journal of Environmental Research and Public Health. Vol. 17, No. 8, pp. 27-88.

HOWELL, Jude. 2019. "NGOs and civil society: the politics of crafting a civic welfare infrastructure in the $\mathrm{Hu}$-Wen period" In: The China Quarterly. Vol. 237, No. 27, pp. 58-81.

HOWLETT, Michael. 2020. "Dealing with the dark side of policy-making: managing behavioural risk and volatility in policy designs" In: Journal of Comparative Policy Analysis: Research and Practice. Vol. 22, No. 6, pp. 612-625.

JIA, Lianrui. 2019. "What public and whose opinion? A study of Chinese online public opinion analysis" In: Communication and the Public, Vol. 4, No. 1, pp. 21-39.

JONES, Michael J; MELIS, Andrea. 2020. "The continuity of the board of statutory auditors across social, economic and political institutional changes" In: European Accounting Review (Ahead of print). Available online. In: https://doi.org/10.1080/09638180.2020.1761850. Date of consultation: 20/02/2021.

LEACH, Kirk A. 2018. "Cross-Sector community partnerships and the growing importance of high-capacity nonprofits in urban governance: A case study of Camden, New Jersey” In: Ashley E. Nickels; Jason D. Rivera (eds.), "Community Development and Public Administration Theory: Promoting Democratic Principles to Improve Communities". Taylor and Francis, pp. 211-228. London, UK.

LIEBMAN, Alexandr Mikhaylovich. 2010. "Cross-Country Comparisons of Civil Institutions Societies: An Empirical Analysis. Civil Society: Foreign Experience and Russian Practice.” Aleteya. St. Petersburg, Russia.

LIINASON, Miia. 2020. “"Drawing the line” and other small-scale resistances: Exploring agency and ambiguity in transnational feminist and queer NGOs” In: International Feminist Journal of Politics. Vol. 23, No. 1, pp. 102-124.

MCGREGOR, Shannon C. 2019, August 1. "Social media as public opinion: How journalists use social media to represent public opinion” In: Journalism, Vol. 20, No. 8, pp. 1070-1086.

MIZRAHI, Shlomo; VIGODA-GADOT, Eran; COHEN, Nissim. 2021. "Drivers of trust in emergency organizations networks: the role of readiness, threat perceptions and participation in decision making" In: Public Management Review. Vol. 23, No. 2, pp. 233-253. 
ROCHLITZ, Michael; MITROKHINA, Evgeniya; NIZOVKINA, Irina. 2020. "Bureaucratic discrimination in electoral authoritarian regimes: Experimental evidence from Russia" In: European Journal of Political Economy. Available online. In: https://doi.org/10.1016/j. ejpoleco.2020.101957. Date of consultation: 20/02/2021.

SNELLEN, Ignace 2002. "Electronic governance: Implications for citizens, politicians and publicservants" In:International Review of Administrative Sciences. Vol. 68, No. 2, pp. 183-198.

WANG, Yang; HU, Ning; ZUO, Jian; RAMEEZDEEN, Raufdeen. 2020. "Project management personnel turnover in public sector construction organizations in China” Journal of Management in Engineering. Vol. 36, No. 2. (Ahead of print). Available online. In: https://doi.org/10.1061/ (ASCE)ME.1943-5479.0000735. Date of consultation: 20/02/2021.

WHITE, Hayden. 1975. "Metahistory: The Historical Imagination in NineteenthCentury Europe.” Johns Hopkins University Press. Baltimore, USA.

WIKE, Richard; SCHUMACHER, Shannon. 2020, February 27. "Democratic rights popular globally but commitment to them not always strong" In: Pew Research Centre. Available online. In: https://www.pewresearch. org/global/2020/02/27/democratic-rights-popular-globally-butcommitment-to-them-not-always-strong/. Date of consultation: 20/02/2021.

WIKIPEDIA. n.d. "List of Sovereign States in Europe by GDP (PPP) Per Capita." Available online. In: https://en.wikipedia.org/wiki/List_of_sovereign_ states_in_Europe_by_GDP_(PPP)_per_capita. Date of consultation: 20/02/2021. 

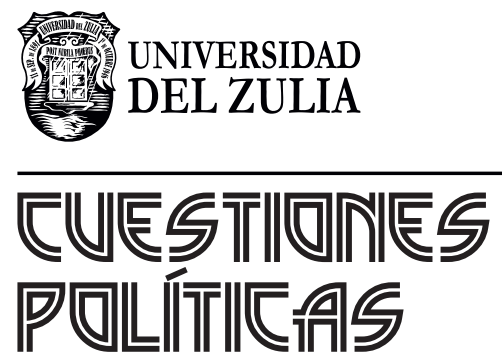

Vol.39 No 69

Esta revista fue editada en formato digital y publicada en julio de 2021, por el Fondo Editorial Serbiluz, Universidad del Zulia. Maracaibo-Venezuela 